\title{
The Occurrence of TDS and Conductivity of Domestic Water in Lumding Town of Nowgong District of Assam, N.E. India
}

\author{
M.K. PAUL ${ }^{1}$ and SUJATA SEN ${ }^{2}$ \\ 'Department of Chemistry, Lumding College, Lumding - 782 447, India. \\ ${ }^{2}$ Department of Geology, Lumding College, Lumding - 782 447, India.
}

(Received: July 12, 2012; Accepted: September 17, 2012)

\begin{abstract}
Total dissolved solid (TDS) and Conductivity are important parameters to determine the quality of water. The seasonal variations in TDS are mainly due to the ionic composition of water. In the present study the seasonal variations in TDS and Conductivity of Lumding Town were studied from May, 2001 to April, 2004. It was found that the TDS of Dug well, Ring well and Ponds were maximum high, but the TDS of River water and Supply water were appreciable.
\end{abstract}

Key words: TDS, Conductivity, Domestic Water

\section{INTRODUCTION}

Water- the elixir of the life system and without it life cannot exist. The diverse uses of water for drinking, cooking, washing, bathing a lot of other purposes. The presence of safe and reliable drinking water is an essential prerequisite for a stable community. So quality of water is to be determined for a locality of various purposes. Water covers about 71 percent of the earth's surface and it is abundant natural resource on the earth. It includes various resources such as rivers, seas, lakes, oceans, glaciers, groundwater, surface water, streams etc. Without water, life of any kind is not possible.

Drinking water quality is a matter of concern as it is related to human health and many hazardous problems may arise due to various pollutants in it. Drinking water sources have been poisoned by directly or indirectly by sewage, pesticides, fertilizers, excess salt, agricultural run off and drainage water from households and also from industrial run off or due to natural geological factors. It is difficult to get pure potable water for public health and water scarcity has led to take unsafe, unconventional water sources. The water balance is also causing change due to human activities like industrialization, deforestation and population explosion.

Water is a "Cradle of life" on which all organism play. As water balances human body in a positive way, it has a negative role in transmitting variety diseases and other pathogenic germs. Many physico-chemical parameters in water is not in a proper way, they have harmful factor. In developing and underdeveloped countries to get pure potable water is a difficult term and contamination of drinking water by domestic and industrial water as well as human and animal excreta is a common feature. If the amount of certain chemicals crosses the permissible limit causes harmful to public health. Many studies have carried out on the quality of drinking water in various parts of the country but for Lumding Town no attempt has been taken so far.

\section{Study area}

The district of Nowgong is situated on the South bank of Brahmaputra occupies a central geographical position in the state of Assam. The

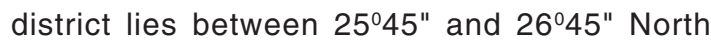
latitudes and 91050" and 93020" East longitudes. 
Lumding Town is 90 Kilometer far South East direction of the Nowgong from the district. The Lumding town is surrounded by Mikir hills (Now N.C. hills/Dima Hasao District) on its three sides (east, west and south) and in the west it is covered by deep forest, which is named as Lanka Forest. The area of Greater Lumding is $411.8 \mathrm{Sq} . \mathrm{km}$ as per 1971 census (Assam District Gazetters, 1978). Lumding Town is a valley like place surrounded by hills and the place is important as it connects the Barak Valley, Upper Assam and Lower Assam by various trains. Its projected population is 2 lakhs. The railway people are dependent on its own supply water, which is irregular, insufficient and limited to only railway areas. The other people depend on dug wells, ring wells, ponds, rivers etc. The place is highly dry area, i.e., during March to May. Weather is pleasant due to high humidity. During the month July - August the temperature becomes very high $35^{\circ} \mathrm{C}$ to $39^{\circ} \mathrm{C}$. The southwest monsoon continues during June to September and during this period $85-90 \%$ rainfall occurs.

There is no major industrial establishment in this town. There are a few factories like soaps, biscuits, potteries, plywood, and brick industries. The brick industries contribute to the soil and the land becomes unfertile and polluted. The big railway industry distributes effluent like burning diesel etc. to the soil and water. There are a few big drain of the railway and its attached area to release polluted waters from the town but there is no proper outlet for them. In civil areas many new drain construction are going on by municipality and PWD. The commercial wastes of the market and household wastes are dumped hither and thither inside the town. Sometimes these wastes are burnt without incinerators. Sometimes proper sanitary systems are not observed. They produce odor pollution and contamination and sewerage goes to the drinking water.

Increase of vehicles with leaded petrol contaminates to the nearby drinking water adjacent to the roads. Sometimes pitching makes water and soil pollution and the people are affected by carcinogen. Village people are dependent on rabi and kharif crops and for them they use various fertilizers and pesticides and ultimately affect their land use pattern and these washed away by surface run off. Overall the modern society uses various non-biodegradable polymeric products they accumulates in water bodies and also penetrates to the soil - thus pollutes the ground and surface water.

During the summer and rainy seasons various people of the locality are affected by water borne diseases like typhoid, dysentery, diarrhea, jaundice etc. and many lives have gone due to these diseases. Aquatic biotas are also affected by consuming polluted water. Common people are not concerned with the chemistry of water because polluted waters occur $80 \%$ of diseases. So it is important to determine the chemical quality of water for human welfare.

\section{Aims and objectives}

Water and its quality is deteriorated day by day by modern civilization, population explosion, household byproducts and sewage materials. The geochemical position of an area are also determines the presence of various chemicals present in drinking and other types of water in a locality. Due to direct relationship of water with human health and so very limited supply of freshwater for domestic purposes, the problems of them were considered.

The following objectives was aim of this study:-

1. To determine the quality of water from various drinking water sources with respect to the total dissolved solid (TDS) and Conductivity.

2. To determine the conclusion regarding the drinking water quality in Lumding Town of Nowgong District of Assam, India.

\section{MATERIALS AND METHODS}

To study the water quality parameters from different sources of Lumding Town of Nowgong District, the samples were collected season wise depending on climatic and geographical conditions of the town.

The samples were collected in different seasons throughout the whole year from to May, 2001 to April, 2004. Water samples were collected in pre- cleaned polythene containers of 2 litres capacity from Dug well (DW), Ring well (RW), Pond 
Table 1: The name of the sampling stations, serial no. and nature of the sources are given below

\begin{tabular}{|c|c|c|}
\hline S. No. & Sampling stations & Nature of source \\
\hline 1. & Nadirpar & DW \\
\hline 2. & Halflong Road & DW \\
\hline 3. & Subash Palley & DW \\
\hline 4. & Patupather & DW \\
\hline 5. & Khanger basti & DW \\
\hline 6. & Santipara & RW \\
\hline 7. & Subash Palley & RW \\
\hline 8. & Ananda Palley & RW \\
\hline 9. & Lanka Road & RW \\
\hline 10. & Upper Babupatty & RW \\
\hline 11. & Nadirpar (East Lumding) & RW \\
\hline 12. & Bazar Area (Main Bazar) & RW \\
\hline 13. & Jarangdisha & RW \\
\hline 14. & New Coloney & RW \\
\hline 15. & Samajbari Area & RW \\
\hline 16. & Buddhamandir & RW \\
\hline 17. & Murabasti & RW \\
\hline 18. & Kamakhya Colony & RW \\
\hline 19. & Loco Coloney & $P$ \\
\hline 20. & Nadirpar (Sitlabari Area) & $P$ \\
\hline 21. & Ananda Palley & $P$ \\
\hline 22. & Halflong Road & $P$ \\
\hline 23. & Santipara & $\mathrm{P}$ \\
\hline 24. & Jarangdisha & $\mathrm{P}$ \\
\hline 25. & Jhulanpool & $\mathrm{R}$ \\
\hline 26. & Lanka Road & $\mathrm{R}$ \\
\hline 27. & Near DRM Office & $\mathrm{R}$ \\
\hline 28 & Balunala & $\mathrm{R}$ \\
\hline 29. & Railway Coloney & RSW \\
\hline 30. & ASEB Area & PHE \\
\hline
\end{tabular}

Abb : DW - Dugwell, $\mathrm{P}=$ Pond, RSW - Railway supply water, RW Ring Well, R - River, PHE - Public Health Engineering supply water.

$(P)$, River water $(R)$, Public Health Engineering (PHE) and Railway supply water (RSW).

\section{Total Dissolved Solids(TDS)}

TDS is determined as according to the APHA procedure. TDS is determined as the residue left after evaporation of the filtered sample

$$
\text { TDS, } \mathrm{mg} / \mathrm{l}=\frac{(A-B)}{V} \times 1000
$$

Where

$\mathrm{A}=$ Mass of dried residue and beaker in $\mathrm{g}$, (after evaporation),

$\mathrm{B}=$ Initial weight of the beaker in $\mathrm{g}$,

$\mathrm{V}=\mathrm{Vol}$. of water taken.

The process is as above of the total solids determined, but here the water samples are filtered by Whatman 40 and having $50 \mathrm{ml}$. sample and then evaporated to dryness and then the beaker dried 


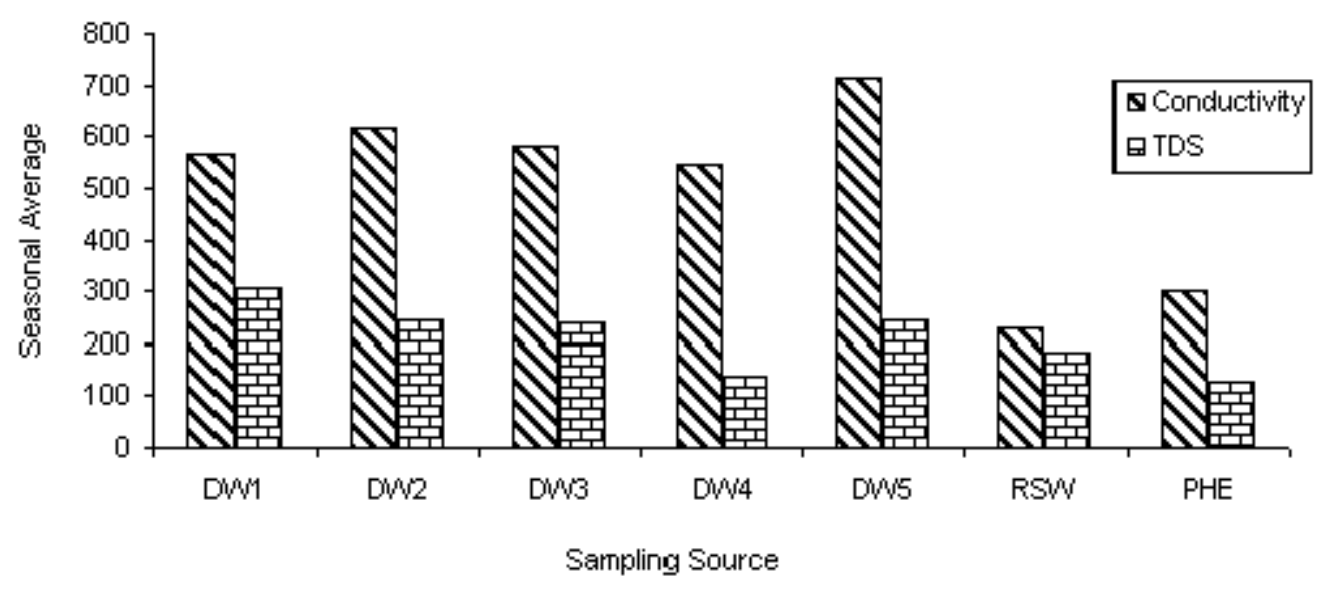

Fig. 1: Relative variation of Conductivity with respect to TDS for Dugwells, RSW and PHE water samples

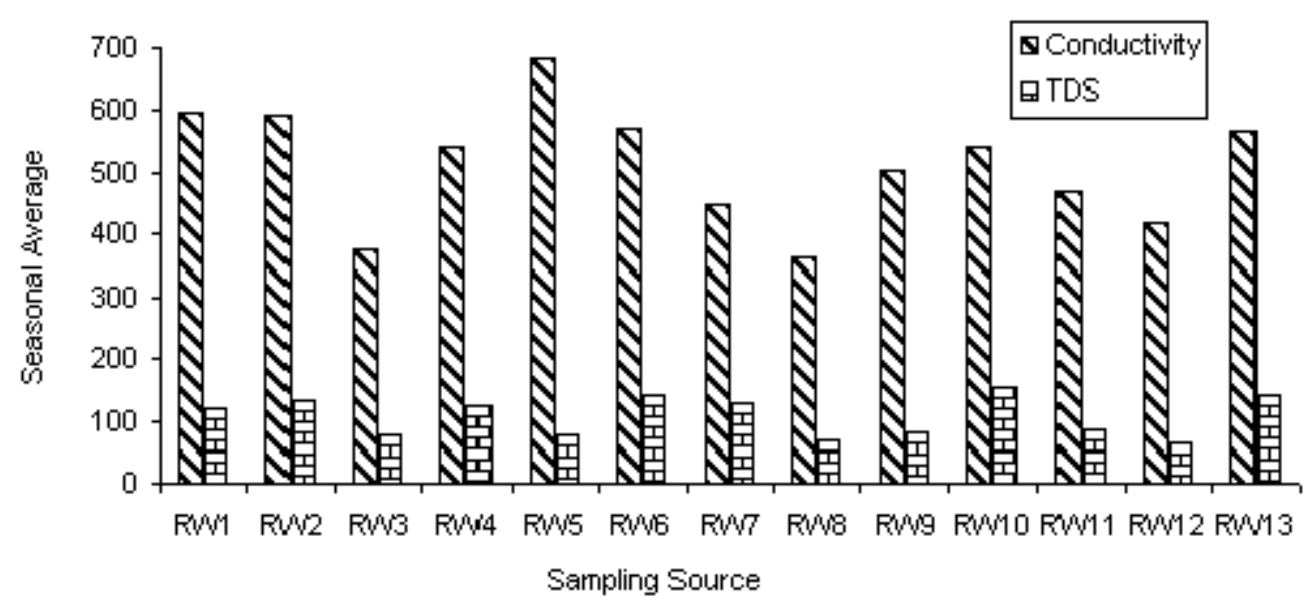

Fig. 2: Relative variation of Conductivity with respect to TDS for Ringwell water samples

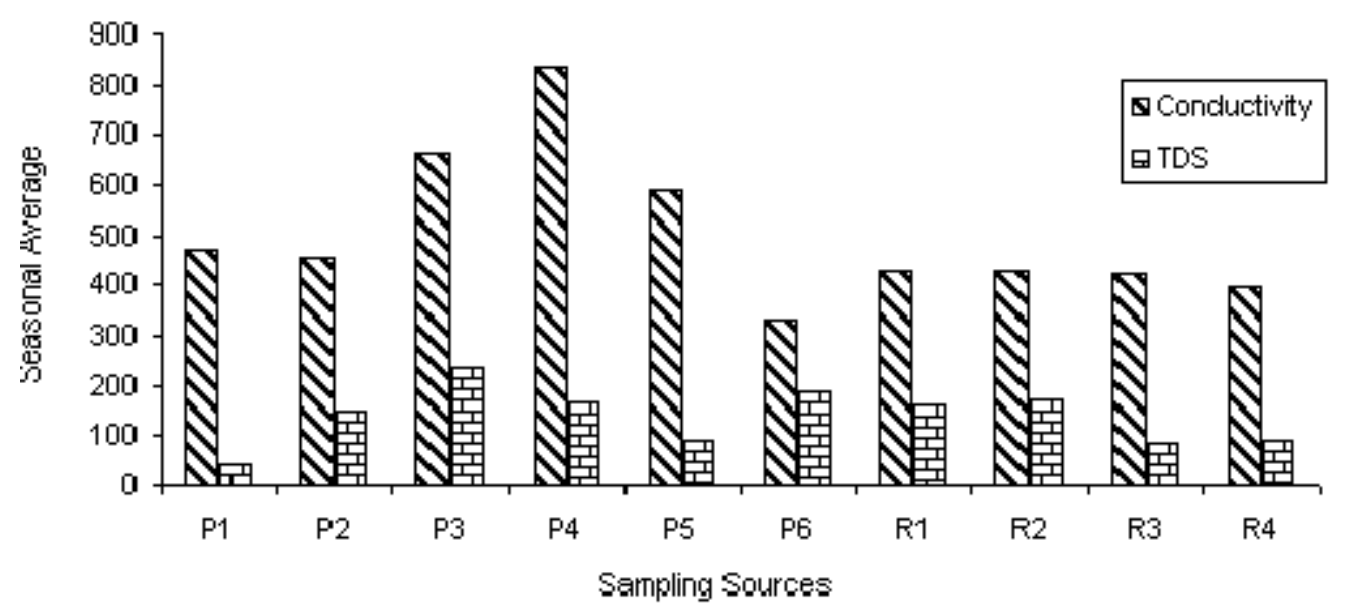

Fig. 3: Relative variation of Conductivity with respect to TDS for Pond and River water samples 


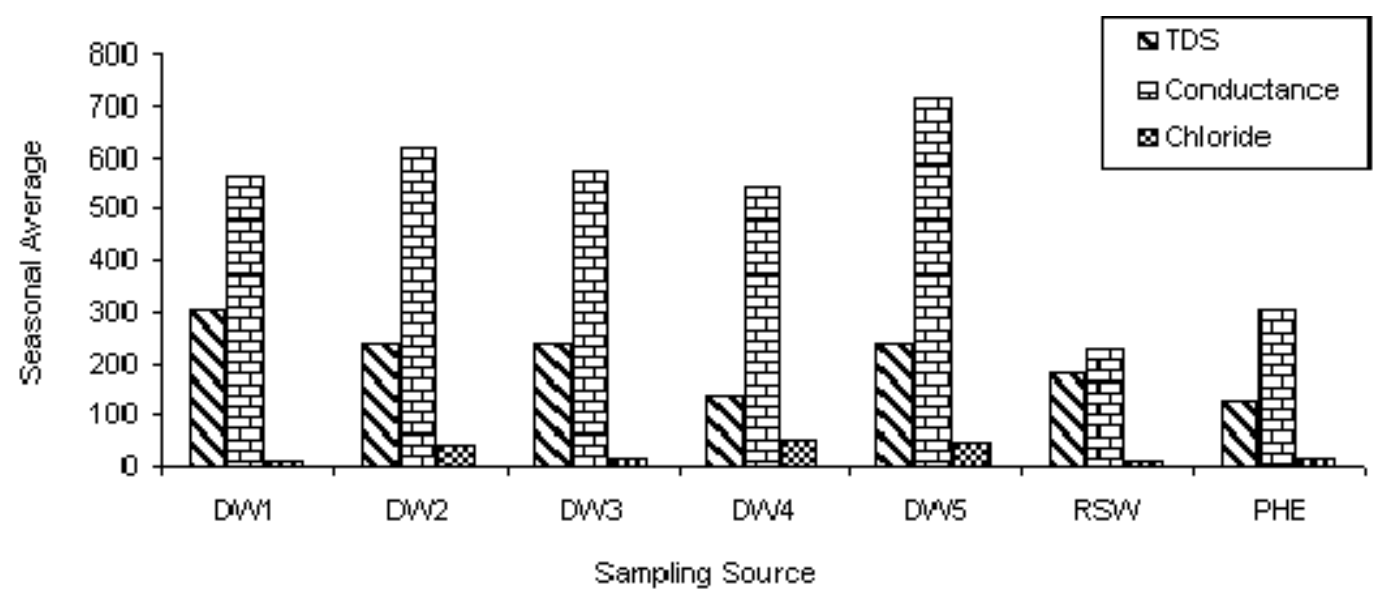

Fig. 4: Relative variation of TDS, Conductance and Chloride (All Season Mean) for dugwells, RSW and PHE water samples

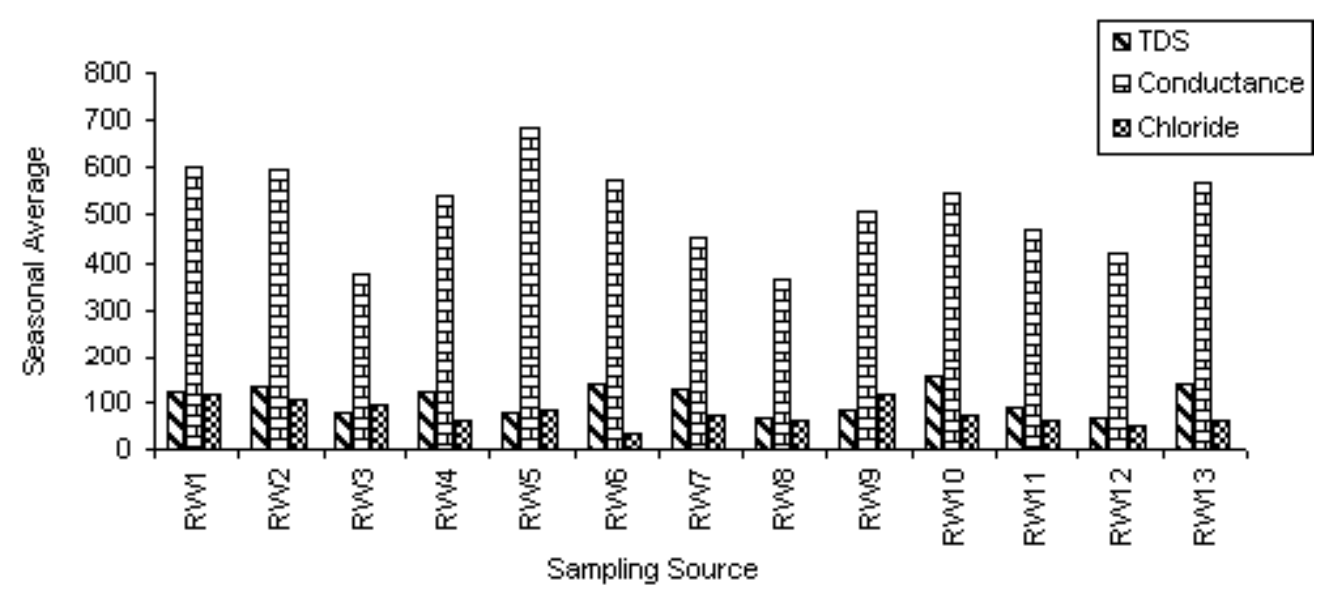

Fig. 5: Relative variation of TDS, Conductance and Chloride (All Season Mean) for ringwell water samples

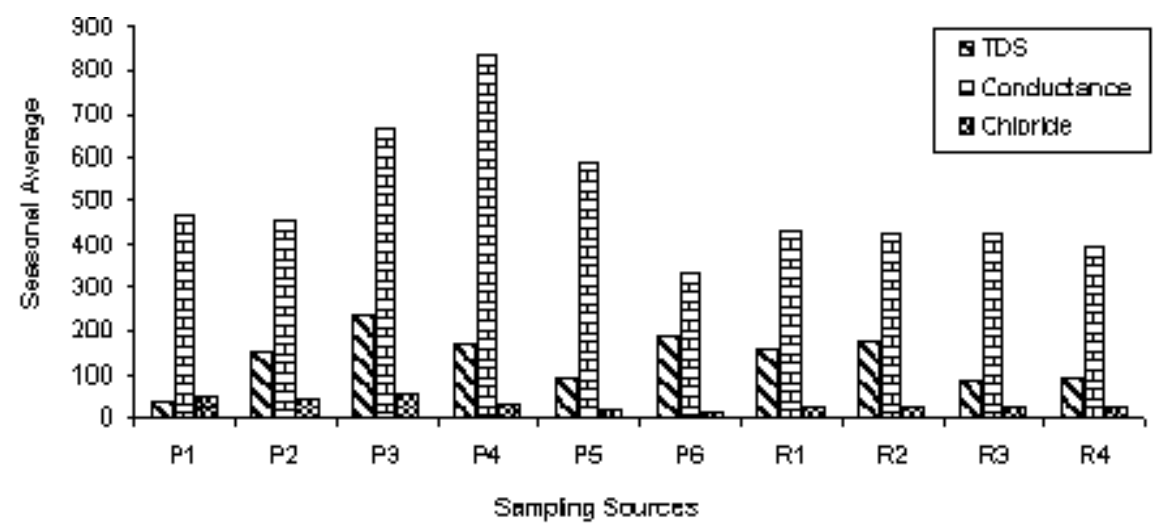

Fig. 6: Relative variation of TDS, Conductance and Chloride (All Season Mean) for Pond and River water samples 
in an oven at $103-105^{\circ} \mathrm{C}$ and weighed. Initial weight of the beaker was also taken.

TDS affects water quality in different ways. Excessive TDS in water imparts a bad taste in water due to mineralization of various salts. A dissolve solid over $2000 \mathrm{mg} / \mathrm{l}$ produces a laxative effect (Kumaraswamy, 1991, Dembere 1998) This is due to Magnesium sulphate along with some sodium sulphate. Sodium parts affect the cardiac part and women with toxemia associated with pregnancy (Train, 1979). The maximum permissible limit of TDS in drinking water is $1000 \mathrm{mg} / \mathrm{l}$ (WHO). For irrigation it is $500 \mathrm{mg} / \mathrm{l}$ and above this limit crops have detrimental effect (Dieborg 1991).

Total dissolved solids can be determined by two methods. In the first method the EC values are multiplied with factor, which is usually, varies from $0.55 \mathrm{mg} / \mathrm{l}$ to $0.75 \mathrm{mg} / \mathrm{l}$ depending upon the nature of ions present. Because electrical conductance and total dissolved solids are independent it is generally agreed that, if the TDS are less than $3000 \mathrm{mg} / \mathrm{l}$, the factor 0.64 (Kumar and king, 2004) can be used to multiply the EC values to obtain the TDS values. In other method, the TDS values can be determined by evaporation technique in which the total solid material will be collected and determined gravimetrically.

\section{Conductivity}

Conductance of water is measured by a digital Conductivitymeter (systronic Model, 304, India) and first calibrated with standard $0.01 \mathrm{M} \mathrm{KCl}$ solution (of conductivity $1287 \mathrm{~ms} / \mathrm{cm}$ at $298 \mathrm{~K}$ ).

The conductivity is not a direct pollution parameter. It helps to give idea about the mineralization of water. The mineralization of ground water is due to perfect entrapment as well as recharge of solubilisation of minerals from soils. Higher mineralization may impart bad taste as potable water (Jain, 1998). Freshly distilled water has a conductivity value of 0.5 to $2 \mathrm{~ms} / \mathrm{cm}$ which changes to $\sim 4 \mathrm{~ms} / \mathrm{cm}$ on standing due to absorption of atmospheric $\mathrm{CO}_{2}$. Drinking water has a conductivity in the range of $1500 \mathrm{mmho} / \mathrm{cm}$ (WHO, 1993).

\section{RESULTS AND DISCUSSION}

\section{Total Dissolved Solids (TDS)}

The TDS contents of water samples are given in the ranges below $15 \mathrm{mg} / \mathrm{l}$ to $530 \mathrm{mg} / \mathrm{l}$ (Dug well water), $10 \mathrm{mg} / \mathrm{l}$ to $300.6 \mathrm{mg} / \mathrm{l}$ (Ring well water), $5.8 \mathrm{mg} / \mathrm{l}$ to $350 \mathrm{mg} / \mathrm{l}$ (Pond water), $45 \mathrm{mg} / \mathrm{l}$ to $253 \mathrm{mg} / \mathrm{l}$ (River water), $80.1 \mathrm{mg} / \mathrm{l}$ to $251 \mathrm{mg} / \mathrm{l}$ (Railway supply water) and $65 \mathrm{mg} / \mathrm{l}$ to $188 \mathrm{mg} / \mathrm{l}$ (PHE supply water).

In this investigation, the highest TDS content $(530 \mathrm{mg} / \mathrm{l})$ was recorded in the dugwell of Nadirpar (DW1) in the premonsoon season and the lowest value $5.8 \mathrm{mg} / \mathrm{l}$ was recorded in the pond water of Loco colony (P1) during monsoon season.

Maximum TDS was observed in the dug wells and ring wells during the pre monsoon was due to the addition of lime and bleaching powder in the wells as well as in the monsoon season for the treatment of water. The maximum permissible limit of TDS in drinking water is $500 \mathrm{mg} / \mathrm{l}$ by USEPA (1996) and $1000 \mathrm{mg} / \mathrm{l}$ (WHO, 1993). In drinking water, the dissolved solids may be due to inorganic salts, organic matter and dissolved gas. A concentration of dissolved solids over $2000 \mathrm{mg} / \mathrm{l}$ produces laxative effect (Dhembare et al, 1998).

The TDS contents of dug well water in Cuddaph town (Andhra Pradesh) were found to be extended over a range of 800-13,464 mg/l, with an average value of $2528 \mathrm{mg} / \mathrm{l}$, which was very much higher than the permissible limit (Kumarswamy, 1991). A high TDS (8704 mg/l) was observed in the east coast of South India (Guru Prasad and Satya Narayan, 2004). Normally ground water has a higher TDS load compared to surface water (Veera Bhadram et al., 2004). Murugesan et al., (2004) showed high TDS (1000 to $1800 \mathrm{mg} / \mathrm{l}$ ) in the ground water quality of seashore, due to seawater enter into the aquifers of the Chennai city of Tamilnadu. High values of TDS are due to salt-water contamination and industrial pollution (Kumar et al., 2005). The TDS content at deeper levels (> 40 $\mathrm{m}$ depth) is comparatively low in all the samples and lies well within desirable limit of $500 \mathrm{mg} / \mathrm{l}$. It 
may conclude that there is more mineralization of ground water at depth upto 40 meters (Jain, 2004).

\section{Conductance}

The values of conductance of water samples are given in Table 4.3 ( $a, b$ and $c)$. The measurement were found in the ranges of $99 \mathrm{mmhocm}^{-1}$ to $1483 \mathrm{mmhocm}^{-1}$ (Dugwell water), $97 \mathrm{mmhocm}^{-1}$ to $1378 \mathrm{mmhocm}^{-1}$ (Ringwell water), $89 \mathrm{mmhocm}^{-1}$ to $1410 \mathrm{mmhocm}^{-1}$ (Pond water), $99 \mathrm{mmhocm}^{-1}$ to $1040 \mathrm{mmhocm}^{-1}$ (River water), $130 \mathrm{mmhocm}^{-1}$ to $300 \mathrm{mmhocm}^{-1}$ (Railway supply water),

$179 \mathrm{mmhocm}^{-1}$ to $400 \mathrm{mmhocm}^{-1}$ (PHE supply water).

Figs 1 to 6 represent ranges and seasonal averages of the conductance of various sources. The highest value of conductance was observed for the water samples of ring well of Patupather (DW4) in monsoon season. Again, the lowest value was observed in the pond water (P5).

The conductivity qualitatively measures the extent of mineralization. The mineralization may be caused of entrapment, ground water recharge and solubisation of minerals from soils. Higher mineralization may impact a bad taste to the potable water (Jain 1998). Drinking water can have a conductivity range of $1500 \mathrm{mmho} / \mathrm{cm}$ (WHO). The conductance values changed from season to season but no clear trend was observed.

Viswanath and Anantha Murthy (2004) showed that high electrical conductivity (1580 $\mathrm{mmho} / \mathrm{cm}$ ) due to septic leakage from households. Prasad et al (2004) showed high conductivity $(13390 \mathrm{mmho} / \mathrm{cm})$ in different sources of ground water Machilipatnam town of Andhra Pradesh, Electrical conductivity of the ground water samples in both Mandya and Maddur towns (Andra Pradesh) ranged from 1524 to $2409 \mathrm{~ms} / \mathrm{cm}$ which indicates the presence of high dissolved solids in ground water samples. (Shivashankara and Sharmila, 2004). A maximum conductivity value of $2210 \mathrm{~ms} /$ $\mathrm{cm}$ and $1914 \mathrm{~ms} / \mathrm{cm}$ was observed at Shasradhara (Dehradun, Uttranchal) was observed during pre and postmonsoon season (Jain, 2004) respectively.

\section{REFERENCES}

1. APHA: Standard methods for the examination of water and wastewater. $19^{\text {th }}$ end. American Public Health Association, Washington, D.C. Assam District Gazzetters 1978 (1995).

2. Dhembere, A. J.; Pandhe, G, M.and Singh, C, R., Groundwater characteristics and their significance with special reference to public health in Pravara area, Maharastra. Poll. Res. 17(1): P. 87-90 (1998).

3. De, Anil, Kumar, Environmental Chemistry. $4^{\text {th }}$ Edn. New Age International $(p)$ Ltd, New Delhi (2002).

4. De, Anil, Kumar and De, Arnab, Kumar, Environmental Education. New Age International Pub Ltd, New Delhi (2004).

5. Guruprasad, B. and Satyanarayan. T., Subsurface water quality of different sampling stations with some selected parameters at Machlipatnam Town. Nat. Env. Poll. Techn. 3(1): P. 47-50 (2004).

6. ISI, Indian Standards for drinking water. IS: 10500:1991 (1991).

7. Jain, C. K., Groundwater quality of District Dehradun, Uttranchal. Ind, J. Env. \& Ecoplan. 8(2): P 475-484 (2004).

8. Kakati, G.N., Study of surface water pollution in Greater Guwahati. A Ph. D.Thesis submitted to G.U (1990).

9. Kumar, Dinesh; Jatin Mukta; Dhindsa, S.S.: Devanda, H.S. and Singh, R.V., Physicochemical characteristics of Amanishah nallah and neighbouring groundwater sources in Sanganeur, Jaipur. Ind. J. Env. Sc., 9(1): P. 71-74 (2005).

10. Kumarswami, N., An approach towards assessment of dug well water quality by physico-chemical characteristics-a case 
study. Poll. Res., 10(1): P.13-20 (1991).

11. Murugesan, S.; Damodhar, Kumar, S.; Lenin, K. and Chandrika, D., Hydrogeochemistry and groundwater quality of seashore region of Chennai, Tamilnadu. Nat. Env. Poll. Tech. 3(3): P. 409-412 (2004).

12. Sarma, B.C.; Misra, A.K. and Bhattacharya, K.G., Metal in drinking water in predominantly rural area. Int. J. Env. Prot. 21(4): P. 315-322 (2000).

13. Sarma, H.P., Quality of drinking water in Darang District, Assam with particular reference to Mangaldoi sub - division. A Ph. D. Thesis submitted to G.U (1997).

14. USEPA, United State Environmental Protection Agency, Washington D.C. Source: Quality Criteria for water by Russel E. Train.1979, USEPA, Washington D.C (1979).

15. Veerabhadram, K.; Ravichandra, M. and Prasanthi, M., Evolution of water quality index at Vishakapatnam city, Andhra Pradesh. Nat. Env. Poll. Tech. 3(1): P. 65-68 (2004).

16. WHO, Guidelines for drinking water quality ( $2^{\text {nd }}$ edn.), WHO, Geneva (1993). 